\section{Properties of Glucoamylase Immobilized on Soluble Polymer}

\author{
Chakamas Wongkhalaung*, Takashi SASAKI** \\ Keiji KaINUma** and Teruo Ohta** \\ ** National Food Research Institute \\ P. O. Box 11 Tsukuba Science City \\ Ibaraki, 305
}

Glucoamylase ( $\alpha-1,4$ Glucan glucohydrolase, Exo1, 4, $\alpha$-glucosidase E.C. 3.2.1.3.) from Rhizopus niveus was immobilized to cyanogen bromide-activated dextran. The glucoamylase-dextran conjugate was purified by gel filtration chromatography. It was found that $92 \%$ of the original protein of the enzyme was recovered in the conjugate and about $82 \%$ of the specific activity of the native enzyme retained. Some properties of the enzyme conjugate were investigated and compared with those of the free enzyme. The $\mathrm{pH}$ activity and $\mathrm{pH}$ stability of the immobilized enzyme were not much altered with the optimum $\mathrm{pH}$ at 5.5 as that of the free enzyme. Immobilized enzyme exhibited a wide range of temperature stability of $50 \sim 60^{\circ} \mathrm{C}$ as compared to the free enzyme. Heat inactivation at $55^{\circ} \mathrm{C}$ had less effect on the residual activity of the immobilized enzyme in which $60 \%$ activity was retained after prolonged heating for 60 minutes.

Immobilization of amylase and glucoamylases on organic and inorganic supports has been investigated by several workers ${ }^{1)-8)}$. Glucoamylase was immobilized on various waterinsoluble supports such as DEAE-cellulose ${ }^{1)}$, granular polyacrylonitrile (PAN) ${ }^{3)}$ and silanized alkylamine glass beads $(\mathrm{CPG})^{6)}$. However, some of the more important industrial substrates such as starch and cellulose will not be effectively acted upon by insoluble forms of immobilized enzymes due to the restricted access of enzyme to substrate. Recent works have shown that a few enzymes can also be attached satisfactorily to soluble supports particularly dextrans of varying molecular weight ${ }^{7)-10}$ ), and high activity and high efficiency of coupling of the enzymes conjugated to cyanogen bromide- activated dextran were also reported ${ }^{8) 9)}$. How ever, little work has been reported on the at tachment of glucoamylase to soluble polymers.

In the present study, the synthesis of gluco. amylase-dextran conjugate and some properties of the conjugated enzyme are described.

\section{Materials and Methods}

\section{Materials}

Glucoamylase (E.C. 3.2.1.3., $\alpha-1,4$ glucan glucohydrolase, Exo-1, 4, $\alpha$-glucosidase) originating from Rhizopus niveus was purchased trom Seikagaku Kogyo Co. Ltd. The enzyme was in a lyophilized form with the activity of 30 Units/mg. Dextran (average m.w. 170000 $\sim 200000$ ) was from Nakarai Chemicals Ltd. Cyanogen bromide, extra pure grade, was obtained from Kanto Chemical Co. Cross-linked dextran in the form of Sephadex G-200 (particle size $40 \sim 120 \mu \mathrm{m}$ ) was from Pharmacia Fine Chemicals. All other Chemicals were of regent grade.

\section{Methods}

(1) Preparation of glucoamylase-dextran conjugate

Glucoamylase was covalently bound to soluble dextran using the cyanogen bromide activation technique as described by Kuo and GoldsteIN ${ }^{9}$. The enzyme-dextran conjugate was separated from unreacted enzyme by Sephadex G-200 gel filtration chromatography at $4^{\circ} \mathrm{C}$ by using 50 $\mathrm{mM}$ phosphate buffer as eluent.

(2) Glucoamylase assay

The activity of free and immobilized glucoamylases was assayed at $40^{\circ} \mathrm{C}, 15 \mathrm{~min}$ by using $1 \%$ soluble starch in $0.05 \mathrm{M}$ acetate buffer at $\mathrm{pH} 4.5$ as substrate. The amount of glucose produced was determined by the NELSON-SOMOGYI method ${ }^{12) 13)}$. Protein content of enzyme solutions was determined by the method of LowRY ${ }^{11}$.

One unit of glucoamylase activity was the amount of enzyme which librated $1 \mu$ mole of glucose per min under the above conditions.

\section{Results and Discussion}

\section{Extent of conjugation}

Absorbance measurement at $280 \mathrm{~nm}$ of the

* Present address: IFRPD, P. O. Box 4-170, Kasetsart University, Bangkok, 10400 Thailand

Offprint requests: T. SASAKI 
eluate fractions revealed the presence of 3 elution regions. The first region (dextran-amylase conjugate) showed high enzyme activity whereas the second (free amylase) possessed very little activity. No activity was observed in the third region. It was found that $92 \%$ of the starting protein was retained in the enzyme conjugate. Specific activity as expressed in terms of glucoamylase unit per $\mathrm{mg}$ of protein was 27.72 units which represents $81.8 \%$ of that of the native enzyme (33.88 units) when both were assayed at $\mathrm{pH} 4.5$ in $0.05 \mathrm{M}$ acetate buffer.

\section{pH profile of immohilized enzyme}

The $\mathrm{pH}$ activity curves for both enzymes were closely similar with maximum activity at pH 5.5. However, the immobilized enzyme also exhibited the optimum $\mathrm{pH}$ activity at $\mathrm{pH}$ 6.0 (99\% relative activity).

The $\mathrm{pH}$-activity profile of immobilized glucoamylase was shifted by $0.2 \sim 0.5 \mathrm{pH}$ units to the allaline side. The free enzyme showed slightly higher activity in the acidic $\mathrm{pH}$ regions between 2.5 and 4.5. The stability towards various $\mathrm{pH}$ buffers of immobilized enzyme was not different from that of the free enzyme.

Temperature stability of immobilized enzyme

The optimum temperature for enzyme activity was determined by incubating the enzyme solution at various temperatures between 37 to $40^{\circ} \mathrm{C}$ in the presence of $1 \%$ soluble starch in $0.05 \mathrm{M}$ acetate buffer (pH 4.5). The immobilized enzyme exhibited a wider range of maximum activity $\left(50 \sim 60^{\circ} \mathrm{C}\right)$ than the free enzyme $\left(50^{\circ} \mathrm{C}\right)$. Both forms of enzyme lost about $80 \sim 85 \%$ of their activities at $65^{\circ} \mathrm{C}$ and about $90 \%$ at $70^{\circ} \mathrm{C}$ (Fig. 1).

Free and immobilized enzyme solutions, containing about $3.5 \mu \mathrm{g}$ protein in $0.05 \mathrm{M}$ acetate buffer ( $\mathrm{pH}$ 5.5) were preincubated for 10 minutes at different temperatures between 37 and $60^{\circ} \mathrm{C}$ in the absence of substrate. The immobilized enzyme was more resistant to heat inactivation than the free enzyme during the temperatures $50 \sim 55^{\circ} \mathrm{C}$. The loss of activity was only $1 \%$ at $50^{\circ} \mathrm{C}$ and $12 \%$ at $55^{\circ} \mathrm{C}$, while the free enzyme lost 13 and $20 \%$ of its activity at 50 and $55^{\circ} \mathrm{C}$, respectively.

The enzyme still retained $60 \%$ of its activity

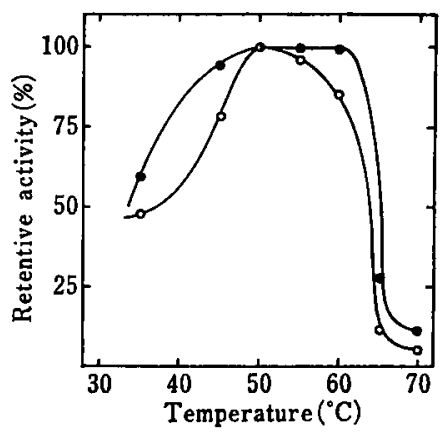

Fig. 1 Thermal stability of free (-O-) and immobilized (--) glucoamylase based on $15 \mathrm{~min}$ reaction at different temperatures in $50 \mathrm{mM}$ acetate buffer at $\mathrm{pH} 4.5$

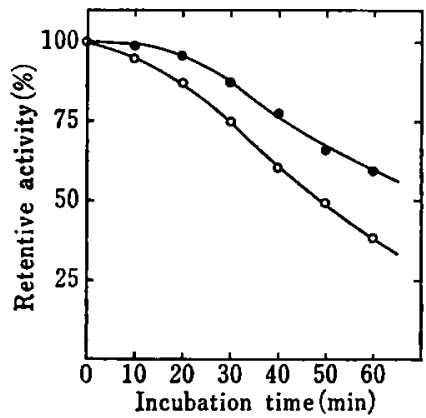

Fig. 2 Heat inactivation of free (-O-) and immobilized (- -) glucoamylase

Enzyme solution were held at $55^{\circ} \mathrm{C}$ in $50 \mathrm{mM}$ acetate buffer at $\mathrm{pH} 4.5$ and samples were removed at $10 \mathrm{~min}$ intervals for the assay.

after heating for $60 \mathrm{~min}$. Free enzyme was more unstable than the immobilized enzyme with the loss of 10 and $60 \%$ activity after 20 and 60 minutes, respectively (Fig. 2).

Acknowledgements : This work was supported by grants from the Research Council, Ministry of Agriculture, Forestry and Fisheries (BCP 84-V-1-13), and Science and Technology Agency.

\section{References}

1) Bachler, M. J., Strondberg, G. W. and Smiley, K. L. : Biotechnol. Bioeng., 12, 85 (1970).

2) Marshall, J. J. and Rabinowitz, M. L. : Arch. Biochem. Biophys. 167, 777 (1975).

3) Handa, T., Hirose, A. and Yoshida, S. : Bio- 
technol. Bioeng., 24, 1639 (1982).

4) Kyesitadze, G. I. and Dvali, M. Sh. : Biotechnol. Bioeng. 24, 1765 (1982).

5) Handa, T., Hirose, A., Akino, T. and WataNABE, K. : Biotechnol. Bioeng. 25, 2957 (1983).

6) Labarzewsi, L. and Paszazynski, A. : Biotechnol. Bioeng. 25, 3027 (1983).

7) Marshall, J. J. and Rabinowitz, M. L. : $J$. Biol. Chem. 251, (4), 1081 (1976).

8) Marshall, J. J. and Humphreys, J. D. : Biotechnol. Bioeng. 19, 1739 (1977).

9) Kuo, J. Y. and Goldstein, J. : Enzyme Microb. Technol. 5, July, 285 (1983).

10) Porath, J., Axen, R. and Ernback, S. : $\mathrm{Na}$ ture, 215, 1491 (1959).

11) Lowry, O. H., Rosenbrough, N. J., Farr, A. L., and Randall, R. J. : J. Biol. Chem. 193, 265 (1951).

12) Nelson, N.: J. Biol. Chem. 153, 375 (1944).

13) Somogy , M.: J. Biol. Chem. 195, 18 (1952).

(Received May 22, 1984)
可溶性高分子に固定化したグルコアミラーゼの性質

$$
\text { チャカマウォンカャラング* }
$$

佐々木堯 ${ }^{* *} \cdot$ 貝沼圭二**・太田輝夫**

( *カサセート大学食品開発研究所,

**食品総合研究所)

グルコアミラーゼ (Rhizopus niveus 起源 $\alpha-1,4$ グル カングルカとドロラーゼ）の水溶性高分子への固定化 法とその特性について検討し。グルコアミラーゼは, シ アノゲンブロマイドで活性化したデキストランへ固定し た。ついで, セファデックス G-200カラムにより未反応 の遊離酵素を除いて固定化酵素を精製した。使用した酵 素タンパク質の $92 \%$ が固定され，活性の $82 \%$ が保持さ れる結果を得た。固定化グルコアミラーゼの最適 $\mathrm{pH}$, $\mathrm{pH}$ 安定性は，未処理の酵素とほぼ同じ值（pH 5.5）を 示した。しかしながら，本固定化酳素の特長は熱安定性 に認められ，末処理酵素の $50^{\circ} \mathrm{C}$ に対 L， $50 \sim 60^{\circ} \mathrm{C}$ の広

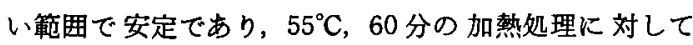
も60\%の残存活性を示した。 